\title{
Reference Dosimetry and Calibration of Glass Dosimeters for Cs-137 Gamma-rays
}

\author{
Young Min Moon ${ }^{\dagger}$, Dong Joo Rhee*, Jung Ki Kim*, Yeong-Rok Kang*, \\ Man Woo Lee*, Heuijin Lim*, Dong Hyeok Jeong* \\ * Research Center, Dongnam Inst. of Radiological \& Medical Sciences, \\ ${ }^{\dagger}$ Department of Materials Physics, Dong-A University, Busan, Korea
}

\begin{abstract}
In this research, the glass dosimeter was calibrated to measure the standard absorbed dose of the Cs-137 irradiator and absorbed dose in a biological sample. Absorbed dose in water for Cs -137 gamma ray was determined by the IAEA TRS-277 protocol. The PTW-TM30013 ion chamber and the PTW-TM41023 water phantom were utilized for measuring absorbed dose and the value was compared with the reading from DoseAce GD-302M glass dosimeter from Asahi Techno Glass Corporation for its calibration. The uncertainty of measurement $(1 \sigma)$ of the calibrated glass dosimeter was $2.7 \%$ and this result would be applied to improve the accuracy in measurement of absorbed dose in a biological sample.
\end{abstract}

Key Words: Cs-137 irradiator, TRS-277 protocol, Glass dosimeter

\section{INTRODUCTION}

The Cs-137 irradiator emits mono-energetic photon of 662 $\mathrm{keV}$ and is often used for the calibration of radiation measurement devices and the irradiation for various researches. ${ }^{1)}$ Specifically, Cs-137 has half-life of 30.2 years so the source replacement happens to be rare and thus the source is suitable for the biological research. ${ }^{1,2)}$ The biological samples is either the cultured cell in a dish or a house mouse. The accurate measurement of the absorbed dose in such samples is required to increase the confidence level of the research. ${ }^{3)}$ However, the absorbed dose measurement depends on the type of the radiation source, its energy, and the type of the samples so the irradiation conditions should be considered before the measurement. Therefore, the calibration data for the dosimeter under different conditions needs to be established and applied.,3)

This research was supported by National R\&D Program through the Dongnam Inst. of Radiological \& Medical Sciences funded by the Ministry of Science, ICT \& Future Planning (50497-2013).

Submitted August, 7, 2013, Accepted August, 20, 2013

Corresponding Author: Dong Hyeok Jeong, Research Center, Dongnam Inst. of Radiological \& Medical Sciences, 40, Jwadong-gil, Jangan-eup, Gijang-gun, Busan 619-953, Korea

Tel: 051)720-5813, Fax: 051)720-5826

E-mail: physics7@empal.com
In order to give the accurate amount of dose to the biological sample, firstly, calibration of the dosimeter is conducted according to the standard absorbed dose, then direct measurement of the absorbed dose inside the sample is by inserting the dosimeter into the sample. In this research, the glass dosimeter which is preferred to be used in the biological research was calibrated by being compared with the standard Cs-137 absorbed dose.

The commercial glass dosimeter has become popular in radiotherapy field due to its reproducibility. Furthermore, the dose measurement in water is capable because the glass device is located into a holder so that the dosimeter can be waterproofed with a simple tube. On the other hand, thermoluminescent dosimeter (TLD) is difficult to reuse, reproduce and waterproof.

In this research, the standard absorbed dose of the Cs-137 irradiator was measured to calibrate the glass dosimeter used in the biological research. In material and method section, the method for the standard absorbed dose measurement would be discussed and in the result section, the data would be presented. In discussion section, the uncertainty of measurement would be analyzed and the further research would be suggested. 


\section{MATERIALS AND METHODS}

IAEA TRS-277 protocol $(1996)^{5)}$ was applied to calculate the absorbed dose of Cs-137 in water. In TRS-277 protocol, water absorbed dose was calculated based on the air kerma and became the basis of the equations presented in TRS-398 protocol (2000). ${ }^{6}$ In this research, because the irradiator was calibrated according to the air kerma at the distance of $1 \mathrm{~cm}$ in air it is reasonable to convey the research based on air kerma and thus using the TRS-277 protocol.

The Cs-137 irradiator (Gamma Irradiator, Chiyoda Technol, Japan) was produced for the low dose radiobiological research.

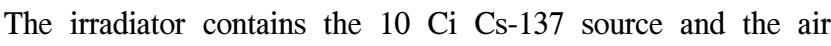
kerma at $1 \mathrm{~m}$ away from the source is about $30 \mathrm{mGy} / \mathrm{h}$.

In this measurement, the TM30013 (PTW, Germany) ion chamber and the Unidose (PTW, Germany) electrometer were used. The electrometer was calibrated from Physikalisch-Technische (PTW-Freiburg) according to the air kerma calibration factor of Co-60 beam. TM30013 and TM30006 ion chambers have the same structure: use PMMA for the chamber walls (thickness: $0.541 / \mathrm{cm}^{2}$ ) and the buildup caps (thickness: $0.541 / \mathrm{cm}^{2}$ ) and aluminium for the central electrodes. Fig. 1, 2 shows the geometrical setup of the measurement,

Before the measurement, the devices were placed in the irradiation room with the constant pressure and temperature for 12 hours to achieve the thermal equilibrium of the phantom and

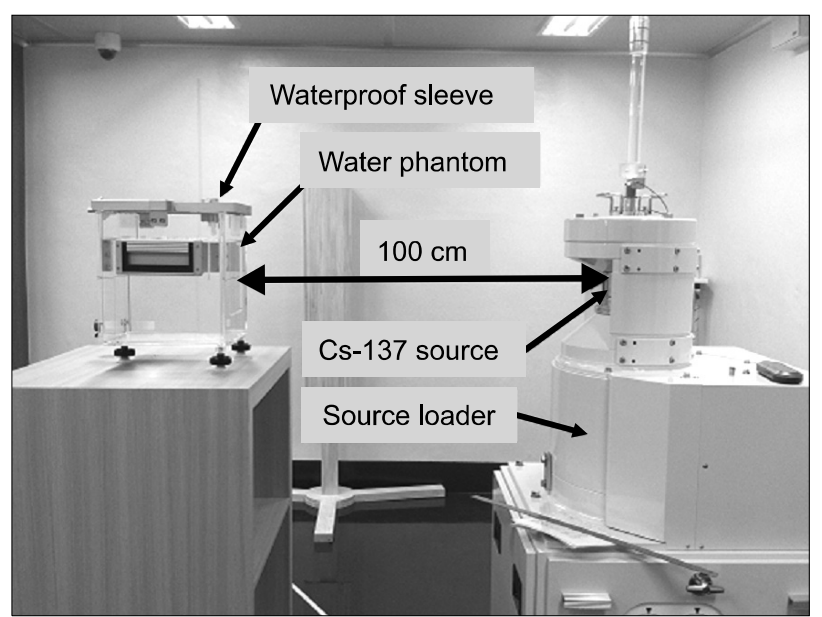

Fig. 1. A photography of geometrical setup for measuring absorbed dose to water for a Cs-137 gamma-ray irradiator. the ion chamber. Temperature and pressure were measured with the thermometer SK-1250 (SATO, Japan) and the barometer OPUS10 (Lufft, Germany) which were calibrated from the certified calibration labs, KCS (Busan) and KCC (Busan), respectively. The calibrated factors were applied to the measurement so that the traceability of calibration was conserved. The average value from the 5 measurements (10 minutes per measurement) became the final result and the standard deviation of the measurements were taken to be the uncertainty of measurement.

According to IAEA TRS-277-2nd(1996), absorbed dose at the standard depth was defined to be

$D\left(z_{\text {ref }}\right)=M k_{T P} N_{K}(1-g) k_{m} k_{a t t} s_{w, \text { air }} p_{u} p_{c e l} p_{\text {dis }}$

where

$M$ : Reading from an ionization chamber in unit of Coulomb,

$k_{T P}$ : Correction factor to account for the temperature and the pressure in the air cavity of an ionization chamber,

$N_{K}$ : Air kerma calibration factor of an ionization chamber,

$g$ : Fraction of energy of secondary charged particles that is lost by bremsstrahlung,

$k_{m}$ : Factor to take account of non-air equivalence of chamber wall and buildup cap materials,

$k_{a t t}$ : Factor to allow for attenuation in the walls of an ionization chamber,

$s_{w, \text { air }}$ : Average stopping power ratio between water and air for electrons from Cs-137 gamma ray

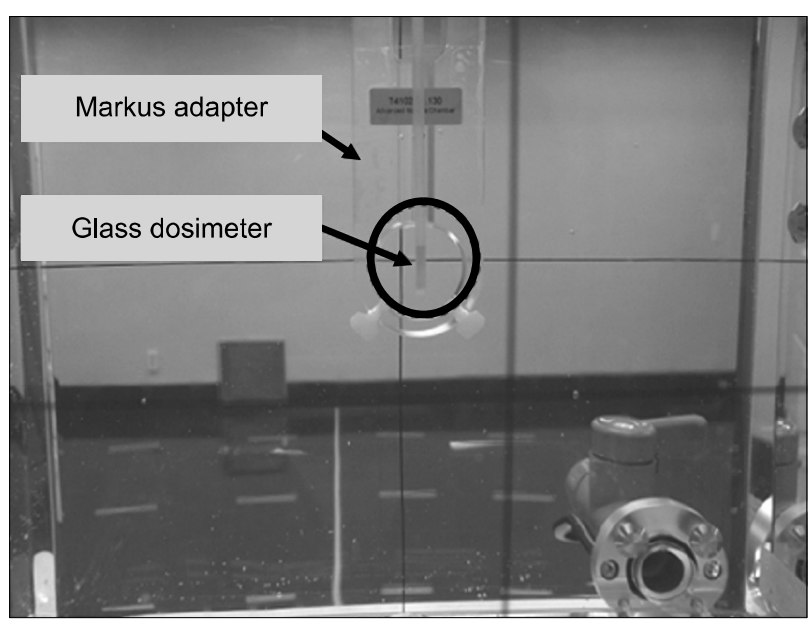

Fig. 2. A glass dosimeter located at a depth in water using Markus chamber adaptor. 
$p_{u}$ : Perturbation correction factor for the different properties in electron interactions in the chamber wall and water and electron scattering in air and in water replaced by the air cavity, and

$p_{\text {dis }}$ : Displacement correction.

The model GD-302M (Asahi Techno Glass, Japan) glass dosimeters were calibrated. GD-302M dosimeter has a cylindrical shape with the diameter of $0.3 \mathrm{~cm}$ and the length of 1.3 $\mathrm{cm}$. Reading of the glass dosimeter was performed with FGD-1000 (Asahi Techno Glass, Japan). The calibration of the glass dosimeter was done by comparing the reading from each glass dosimeter with absorbed dose measured by the ionization chamber. However, the glass dosimeter reader converted the value by the comparison between the reading from the glass dosimeter and the standard reference glass. This conversion assumed that the same model of the glass dosimeters would have the same responses to the irradiation so the application of independent calibration factors for each dosimeter was impossible. In this research, the converted values were taken without any corrections and they would be presented as $G_{i}$ (Glass dose for dosimeter $i$ ). Although this does not identify the variations between the glass dosimeters and would increase the uncertainty in the final results, it could be a more practical method.

In this study, the calibration factors of 6 glass dosimeters were obtained as the acquisition of the baseline data.

Firstly, the net glass dose $\mathrm{G}$ was defined to be

$G_{i}=G_{i, \text { read }}-G_{i, \text { pre }}$

where $G_{\text {pre }}$ is the reading from the dosimeter before irradiation and $G_{i, \text { read }}$ is the reading after irradiation. Although the unit of $G$ is supposed to be $\mu \mathrm{Gy}$ in the reader, the unit of $\mathrm{G}$ would be presented as $\mu \mathrm{Gy}$-gr (glass reading) or mGy-gr in this paper to be distinguished with the unit of absorbed dose. Therefore, the calibration constant of the glass dosimeter is following.

$N_{i}=\frac{D_{r e f}}{R}[\mathrm{mGy} / \mathrm{mGy}-\mathrm{gr}]$

\section{RESULT}

The factors used in the absorbed dose calculation were suggested in TRS-277 except for $p_{\text {dis }}$ from TRS-398. Both the factors and the measured data are presented in Table 1 . The absorbed dose at the standard depth was measured to be 26.12 $\mathrm{mGy} / \mathrm{h}$. The readings and the calibration factors for the 6 glass dosimeters were demonstrated in the Table 2. The relative standard deviation of each glass dosimeter became $0.2 \%$ from

Table 1. Values for Cs-137 gamma rays in TRS-277 protocol, " $k_{T P}$ corrected.

\begin{tabular}{lc}
\hline \hline Physical quantity & Values for Cs-137 gamma rays \\
\hline$M(\mathrm{pC})$ & $80.25^{*}$ \\
$N_{K}(\mathrm{cGy} / \mathrm{nC})$ & 5.016 \\
$(1-g)$ & 0.997 \\
$k_{m} k_{a t t}$ & 0.973 \\
$\alpha$ & 0.51 \\
$S_{w, \text { air }}$ & 1.136 \\
$S_{\text {wall,air }}$ & 1.107 \\
$\left(\bar{\mu}_{\text {en }} / \rho\right)_{w, w w a l l}$ & 1.029 \\
$p_{u}$ & 1.001 \\
$p_{\text {dis }}$ & 0.988 \\
Dose $(\mathrm{mGy})$ & 4.385 \\
Dose $(\mathrm{mGy} / \mathrm{h})$ & 26.12 \\
\hline \hline
\end{tabular}

Table 2. Dosimeter readings, its standard deviations, and calibration factors for 6 glass dosimeters.

\begin{tabular}{cccccc}
\hline \hline & $G_{p r e} \pm \mathrm{SD}(\mu \mathrm{Gy}-\mathrm{gr})$ & $G_{\text {read }} \pm \mathrm{SD}(\mu \mathrm{Gy}$-gr $)$ & $R \pm \mathrm{SD}(\mu \mathrm{Gy}$-gr $)$ & Relative SD $(\%)$ of $R$ & $N_{i}(\mathrm{mGy} / \mathrm{mGy}$-gr $)$ \\
\hline 1 & $720 \pm 1.89$ & $4,755 \pm 9.46$ & $4,035 \pm 9.64$ & 0.23 & 1.086 \\
2 & $712 \pm 1.27$ & $4,752 \pm 8.20$ & $4,040 \pm 8.30$ & 0.20 & 1.085 \\
3 & $704 \pm 1.90$ & $4,702 \pm 8.99$ & $3,998 \pm 9.19$ & 0.22 & 1.097 \\
4 & $704 \pm 1.87$ & $4,700 \pm 9.62$ & $3,996 \pm 9.80$ & 0.24 & 1.097 \\
5 & $706 \pm 1.10$ & $4,785 \pm 9.39$ & $4,079 \pm 9.45$ & 0.23 & 1.075 \\
6 & $687 \pm 1.83$ & $4,713 \pm 7.76$ & $4,026 \pm 7.97$ & 0.20 & 1.089 \\
\hline \hline
\end{tabular}

Variation of glass dosimeters: $0.8 \%$ 
Table 3. Uncertainty estimations of calibration of the glass dosimeters in this study.

\begin{tabular}{|c|c|c|}
\hline \multirow{2}{*}{$\begin{array}{c}\text { Type of physical quantity } \\
\text { or procedure }\end{array}$} & \multicolumn{2}{|c|}{ Estimated uncertainty } \\
\hline & Applied value & Relative (\%) \\
\hline $\begin{array}{l}\text { Calibration factor of } \\
\text { ion-chamber }\end{array}$ & - & 0.6 \\
\hline Measured charge & - & 0.5 \\
\hline Temperature correction & $0.05^{\circ} \mathrm{C}$ & 0.02 \\
\hline Pressure correction & $0.01 \mathrm{kPa}$ & 0.01 \\
\hline Interaction coefficients in Eq.(1) & - & 2.6 \\
\hline Timer error & $1 \mathrm{sec}$ & 0.02 \\
\hline Measured distance & $1 \mathrm{~mm}$ & 0.11 \\
\hline $\begin{array}{l}\text { Reference dose from } \\
\text { ion-chamber dosimetry }\end{array}$ & \multicolumn{2}{|c|}{$2.70 \%$} \\
\hline $\begin{array}{l}\text { Dosimeter reading } \\
\text { (maximum) }\end{array}$ & - & 0.24 \\
\hline Holder positioning in water & $1 \mathrm{~mm}$ & 0.11 \\
\hline $\begin{array}{l}\text { Dosimeter response from } \\
\text { reader }\end{array}$ & \multicolumn{2}{|c|}{$0.26 \%$} \\
\hline Total uncertainty & \multicolumn{2}{|c|}{$2.71 \%$} \\
\hline
\end{tabular}

8 readings on average which showed that the reproducibility of the glass dosimeter is acceptable. However, the standard deviation of the 6 glass dosimeters was $0.8 \%$.

\section{DISCUSSION}

The total uncertainty in the calibration factor for a glass dosimeter was calculated as the statistical sum of the measurement uncertainty and the response uncertainty. The estimated total uncertainty of the glass dosimeters in this research was demonstrated in Table 3. The standard absorbed dose results were derived with the given air kerma constant and $k_{T P}$ correction according to the standard temperature and pressure shown in the ionization chamber certificate. While applying the equation (a), the constants were from TRS-277 protocol. The maximum time error in measurement was assumed to be 1 second per hour and the maximum displacement was assumed to be $1 \mathrm{~mm}$. The interaction coefficients in the equation
(1) contributed to uncertainty the most. ${ }^{5}$ ) The uncertainty of a glass dosimeter was estimated with the standard deviation from 8 repeated readings from the same dosimeter and the maximum placement error of $1 \mathrm{~mm}$. The total uncertainty (1 Standard Deviation) was calculated to be $2.7 \%$. The reason for this low total uncertainty was because of the reproducibility of the glass dosimeter as well as the individually derived calibration factors. Even if the glass dosimeters were assumed to have a single calibration factor, the total uncertainty would have increased only by $0.1 \%$ which can be negligible in biological research.

TRS-277 protocol was referred in this study to analyze the absorbed dose of the Cs-137 source but uncertainty of measurement of the glass dosimeter seems to be high. TRS-398 protocol would be applied in near future to reduce the uncertainty of measurement. The results from this paper will be used for the verification of the absorbed dose measured by the glass dosimeter in the biological research using Cs-137 irradiator.

\section{REFERENCES}

1. Jeong DH, Kim JK, Yang KM, et al: Absorbed dose determination for a biological sample irradiated by gamma rays from a Cs-137 source. Korean J Med Phys 22(3):124-130 (2011)

2. Sabine $\mathrm{H}$ : Methods in Radiobiology. Nanodosimetry Workshop (2009)

3. Kwak DH, Moon YM, Kang YR, Lee CY, Jeong DH, Kim $\mathrm{JK}$ : 감마선 조사시 용기의 크기에 따른 흡수선량 평가. $K A R P$ 춘계학술대회 논문집. 2011, Seoul, pp. 282

4. Brady SL, Toncheva G, Dewhirst MW, Yoshizumi TT: Characterization of a $137 \mathrm{Cs}$ irradiator from a new perspective with modern dosimetric tools. Health Phys 97(3):195-205 (2009)

5. TRS-277: Absorbed Dose Determination in Photon and Electron Beams: An International Code of Practice. International Atomic Energy Agency, Vienna (1997)

6. TRS-398: Absorbed dose determination in external beam radiotherapy: an international code of practice for dosimetry based on standards of absorbed dose to water. International Atomic Energy Agency, Vienna (2000) 


\title{
연구용 세슘-137 조사기에 대한 흡수선량 측정과 유리선량계 교정에 관한 연구
}

\author{
*동남권원자력의학원 연구센터, ${ }^{\dagger}$ 동아대학교 신소재 물리학과 \\ 문영민 $^{\dagger}$ • 이동주* · 김정기* · 강영록* · 이만우* · 임희진* · 정동혁*
}

본 연구에서는 방사선생물 분야에서는 사용하는 세슘-137 조사기에 대한 기준 흡수선량을 측정하고 시료의 방사선량 평 가에 활용하기 위하여 유리선량계를 교정하였다. 세슘-137 감마선에 대하여 IAEA TRS-277 프로토콜을 적용하여 정밀하 게 물흡수선량을 결정하였다. 기준 흡수선량 측정에는 PTW-TM300013 전리함과 PTW-TM41023 물팬텀을 사용하였으며, 유리선량계는 DoseAce사의 GD-302M 모델을 사용하였다. 교정된 유리선량계의 불확도(1 SD)는 약 $2.7 \%$ 로 평가되며, 본 결과는 연구용 시료의 방사선량 측정에 이용될 예정이다.

중심단어: Cs-137 조사기, TRS-277 프로토콜, 유리선량계 